\title{
IMPACT OF IMF LENDING ANNOUNCEMENTS ON THE PERFORMANCE OF STOCK MARKET: EMPIRICAL EVIDENCE FROM PAKISTAN Muhammad Azeem $^{1}$, Nisar Ahmad ${ }^{2 *}$,Sarfraz Hussain ${ }^{3}$, Muzammil Khurshid ${ }^{4}$, Safyan Majid ${ }^{5}$ \\ ${ }^{1}$ Assistant Professor, Department of Business Administration, University of Central Punjab, Gujranwala Campus, Pakistan; ${ }^{2 *}$ Assistant Professor Hailey College of Commerce, University of the Punjab Lahore, Pakistan; ${ }^{3}$ Azman \\ Hashim International Business School, Universiti Teknologi Malaysia, Kuala Lumpur, Malaysia, and Govt. Imamia College Sahiwal, Pakistan; ${ }^{4}$ Assistant Professor, Department of Banking and Finance, University of the Punjab, Gujranwala Campus, Gujranwala, Pakistan; ${ }^{5}$ School of Accountancy and Finance, University of Lahore, and GC University Lahore, Pakistan. \\ Email: ${ }^{1}$ azeem.grw@ ucp.edu.pk, ${ }^{2 *}$ nisar@ hcc.edu.pk, ${ }_{5}^{3}$ mianfraz1@gmail.com, ${ }_{5}^{4}$ muzammil.khurshid@ pugc.edu.pk, 5 safyanmajid@hotmail.com
}

Article History: Received on $3^{\text {rd }}$ May 2021, Revised on $17^{\text {th }}$ May 2021, Published on $20^{\text {th }}$ May 2021

\section{Abstract}

Purpose of the study: Stock markets have demonstrated varying reactions to IMF lending announcements across various economies. Announcements offered by IMF often be perceived negatively by the participants of the stock market, because of stringent conditions accompanied with the loan that may oppose the political and economic agenda of a borrowing nation. Thus, this study intends to investigate the impact of IMF's announcements about extending loans to Pakistan on the performance of the Stock market in the debt-ridden economy.

Methodology: For regular returns from 1997 to 2017, the benchmarking indexes of KSE-100 and 30 were used. Meanwhile, IMF lending arrangements are categorized into three respective dummies (standby, extended credit facility, and extended fund facility). The Generalized Autoregressive Conditional Heteroscedastic (GARCH) model was used to investigate the effect of IMF's lending news on the regular stock returns.

Main findings: The results show a statistically significant effect of the IMF's News about lending arrangements on the performance of the stock market in Pakistan. Surprisingly, the negative effect of IMF lending announcements on the performance of the stock market in Pakistan implies that the loans extended by IMF are not professed by speculators as good for the economic performance of the economy.

Application of this study: The findings of this study imply that simply extending loans is not a panacea for politically unstable and financially ruined nations. Lending strategies of IMF need to be favourable for the political and economic conditions of a borrowing country.

Originality/ Novelty: As for as the novelty is concerned, the study has highlighted the time-varying impact of IMF lending announcements on the performance of the stock market in a financially fragile country where a newborn government facing multiple challenges has made its best effort to avoid borrowing from IMF.

Keywords: International Monetary Fund, Lending Announcements, Stock Market Performance, GARCH Model.

\section{INTRODUCTION}

In a financial crunch, often countries seek foreign assistance from International Financial Institutions (IFI), namely, World Bank (WB), International Monetary Fund(IMF), Asian Development Bank (ADP), etc. (Doroodian,1993; Williams \& Nguyen, 2005). Naturally, a country owes to opt for external help to uplift its economy's deadly pace. Specifically, a fiscally retrenched government routinely visits IMF for technical and more pronounced financial remedies (Kutan \& Sudjana, 2003). By following the myth of traditional lenders, IMF indeed imposed assured restrictions on borrowers to secure its principle (Balima \& Amadou, 2020). A fund with margins is an excellent approach to follow? It offers a qualified question to answer; however, different people have different views over it (Rogers, Scotti \& Wright, 2014). The formers argue that the movement of a fund in your country is imperative to regain the tarnished investors' confidence at the time of difficulty (Kern, Reinsberg, \& Rau-Gohring, 2019). Contrarily, the IMF's structural changes may further destabilize the cord of economic escalation. Likewise, one gathering bolsters the IMF by saying that the IMF goes about as the last resort bank (Georgiadis \& Gräb, 2016).

The other group says that even though it is undoubtedly the last resort, it is not required because the IMF imposes certain conditions on the country that may resist the political support that is always needed for structural reforms. Undoubtedly, when a country enters into IMF programs, the decision has deep-rooted effects on its different stakeholders (Bordo \& Schwartz, 2000; Gehring \& Valentin, 2020). Primarily, any developing country responds rigorously to any macrofinancial hilarious. Pakistan and the IMF are the two sides of the same coin. Probably, since from inception, they have made 21 agreements for loans (Remi \& Moradi, 2016). As the IMF, an international organization of 189 nations, aimed to work for international monetary cooperation and stability. Precisely, IMF integrates with other countries through economic surveillance, financial lending, and economic capacity building of member countries. Usually, the IMF offers different lending facilities to its members, namely, stand-alone agreements, concessional facilities, various special facilities, and poverty reduction Growth Trust (PRGT). The lending through PRGT generally offers to low-income 
countries at a relatively low interest. The IMF provides a total of 10 PRGT programs to Pakistan. Additionally, Pakistan has opted for 12 bailouts and standby agreements (SBAs).

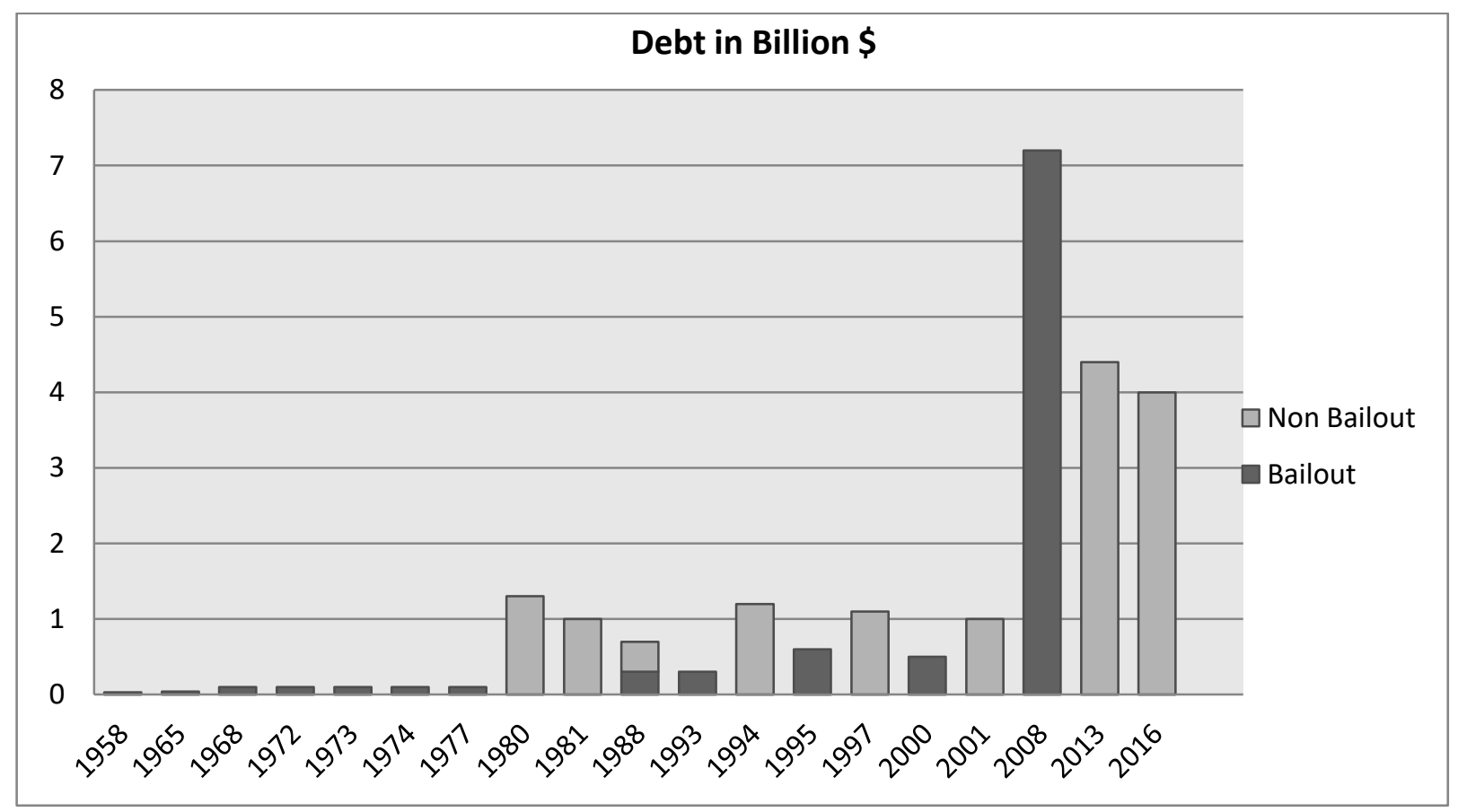

Figure 1: Bailout and Non- Bailout Debt Distribution

\section{Source: IMF Webpage Pakistan Data}

When a country announces entering the IMF program, the NEWS affects the different stakeholders differently. Precisely, any country's capital market responds to these macroeconomic announcements rigorously (Kho \& Stulz,1999; Lane \& Phillips, 2000). The history of capital starts in Pakistan in 1949 with 13 scripts and around Rs. 110 million capital. As the market strived to uphill, the pioneer leading of IMF distorted the cord in 1958 with fractional borrowing of approximately 03 billion dollars. In subsequent years until 1968, Pakistan's economy absorbed additional, other billion dollars through the IMF dowser. Perhaps the pace in the capital market listing of new ventures stumbled a lot of 90 new ventures with 1330 million Pak rupees capital seen in a decade.

As time proceeded, the extent of external aid (IMF Programs) surged. In the next two decades until 1988, the local economy inhaled additional 2.5 billion dollars, surprising in a similar period, less than 100 new ventures were born in the stock market. In the next ten years, from 1990 to 2000, Pakistan welcomed several IMP programs with more than 5 billion dollars borrowing; however, the number of recorded organizations remained 332 with Rs' paid-up capital of 18.8 billion. Since the inception of the $21^{\text {st }}$ century, Pakistan has parked massive IMF funds through multiple deals. The amount above estimated is dubbed as compared to the funds extracted from the IMF since 1958, whereas roughly 90 more companies were entered into the stock market (Tobias., 2020; Kentikelenis, Thomas, \& Stubbs, 2016).

The capital market of Pakistan reacted to the IMF programs all the way through. The market revolves around listed companies and investors; those above often do not like external sanctions and involvements in domestic macroeconomic affairs. In the prior 20 years (1958-178), the Govt. owed seven Bailouts or Stand-by Agreements having longer maturity with tight sanctions coincidentally; the native stock market stayed behind customary norms in the region. Between 1980 and 1995, we were part of another seven programmers and all were one and two years long. However, the conditions were softer than before, and resultantly, our market produced positive numbers concerning listing and trading $\underline{\text { Ben \& }}$ Robles, 2021).

Between 1997 and 2013, the time PML-N obtained the last \$6.4 billion, there were six programs. Substantive emergence witnessed in the stock market progression, namely, doubling the figure of listed ventures, the staggering surge in capitalization and prominently, naming the best performance award, etc. Perhaps, it was due to the softness of IMF sanctions towards Pakistan's economy and possibly positively welcomed by capital market players. Aforementioned, the discussion affirms that every IMF move has a historical association with stock market performance. Notwithstanding, our stock market has also absorbed the heat generated even following every permissible IMF adventure in Pakistan. Therefore, the study is organized to probe the likely effect of IMF lending announcements as a source of news on the stock market: by studying investors' behavior in the form of returns (Couharde, Bennani \& Wallois, 2021). IMF-related news and announcements generally have diverse impacts on secondary market performance. Moreover, the existing literature also showed that several methodologies and techniques were applied to investigate the pulse of relationships above. Expressly, the lending agency IMF has provided bailout programs in different regions of the world and assisted 
the economies during the financial crunch. Out of 195 recognized estates, 179 have directly and indirectly been exposed to said agency, and significantly, Pakistan has fastened ties with IMF for so long. Resultantly, IMF has massive inversion in our economic policy formation that needs to address empirically. Investors discount the macroeconomic events in international or national contexts while forming the par value (Fraiberger, Lee, \& Rancier, 2018). Resultantly, the indices of given stock markets correlate with Macroeconomic NEWS's intensity and integrity. Most countries depend on external financial assistance for corrective fiscal deficit moves. Especially, developing countries have substantial interactions with external funds providers such as IMF, ADB, World Bank, Euro-Investors groups \& so on. The entire economic structure of fiscal deficit countries is based on IMF bailouts; hence secondary market investors of said countries heavily embark on donors' announcements towards the recipients. Briefly, the countries that substantially depend on IMF loans their stock markets actively react with each debt agreement.

The economy of Pakistan majorly finances through IMF trenches since its inception. Nevertheless, most of our local scholars have established that Macroeconomic variables have a significant impact on stock prices. Meanwhile; they ignored an integral macroeconomic event: IMF announcements that strongly impact the stock price each time by seeing our economy's inherited feature. Additionally, the substance is still less explored in the international arena thus far. Therefore, the said study effectively bridges this gap by exploring the probable impact of IMF announcements on the performance of the stock market in Pakistan.

The said study contributes to the existing literature body on several grounds. Firstly, most of the studies, either in international or in national contexts, substantially stressed that investors consider all macroeconomic events while estimating the deemed stock's par value. Meanwhile, they have not addressed that IMF announcements are also an integral macroeconomic event. Secondly, in developing economies where external financing is a significant source to cover fiscal space, IMF plays a handsome bit of chunk to cope with the need. Pak-IMF relationship is imperative to learn because, all the time, the IMF rescued our turbulent economy through financial assistance. Therefore, the pivotal role of the IMF in native financial restructuring and its ultimate out marks, especially in the capital market, has not been addressed ahead of; hence, the said study is a first endeavor to probe so. Thirdly, to measure the time-varying volatility of return caused by lending news, we prefer using the GARCH $(1,1)$ approach for all news types. Additionally, we made use of the "Heteroscedasticity-Consistent Covariance Matrix" to tackle the issue of non-normality of returns; perhaps, the results may consider more consistent as compared with OLS estimations in contrast. Because it is imperative to properly gauge the time-varying impact of IMF announcements on daily stock market returns.

Henceforth, the body of knowledge concerning IMF-Pakistan's capital market response is still vacant. Thus the present study seeks to cover this gap by investigating the impact of IMF's announcements about extending loans on the performance of the Stock market in Pakistan.

\section{LITERATURE REVIEW}

This section describes an overview of the previous studies concerning the IMF-related programs and their influence on the stock, bond, and foreign exchange markets. The IMF's part to regulate the international monetary system has been extensively studied in existing studies. Different researchers from different aspects have discussed the impact of IMF programs on the developed and emerging stock markets (Tillmann, 2001; Kamin, 2002; Eichengreen, Kletzer \& Mody, 2005; Williams \& Nguyan, 2005; Fayad, Huang, \& Zhao, 2020; Sever, Goel, Drakopoulos, \& Papageorgiou, 2020). Some European, East Asian, South Asian, and Far-East countries have availed the International Monetary Fund's bailout programs. Some empirical studies have focused on the IMF-related announcement and its consequences on the stock market returns. In Greece, Kosmidou, Kousenidis, and Negakis (2015) have tested the impact of the IMF bailout program on the different sectors of the Athens Stock Market during the debt crisis in Greece from 2009 to 2012 by using an unrelated regression model, and they concluded that these actions could not overcome the real situation.

Moreover, Kutan, Muradoglu, and Sudjana (2012) carried out a study in the Far East stock markets to discuss the impact of IMF programs on the financial and real sector and concluded that IMF-related news has different effects on different sector returns. Evrensel and Kutan (2007) carried out a study on the announcements of IMF and their impact on the Indonesian, Thai and Korean stock market returns by comparing financial and non-financial sectors during the Asian crisis through ML-GARCH Model and the study concluded that IMF related announcements positively influenced the returns of these stock markets.

Furthermore, Brealey and Kaplanis (2004) studied the IMF-related news by taking a sample of IMF programs, and they found a significant decline in stock prices due to IMF programs. Kho and Stulz (2000) made a study to point out the impact of IMF aid on the Korean banks during the Asian crisis, and they concluded that there is no impact of the IMF program on the banking sector and does not minimize the systematic risk. Kho, Lee, and Stulz (2000) investigated the IMF program's announcement dates during the crisis and found a significant influence of IMF news on US banks' returns. However, Evrensel and Kutan (2008) studied the forward exchange rate and the IMF-related announcements by applying the GARCH model. The results demonstrate that IMF announcements are associated with Indonesian rupiah and Korean baht when country-specific data is used. Besides, Kutan and Sudjana (2003) investigated the impact of IMFrelated news on the Indonesian stock market and suggested that IMF news does not cause investors' problems. 
Table 1: International and National Evidence

\begin{tabular}{|c|c|c|}
\hline Authors & Title & Remarks \\
\hline $\begin{array}{l}\text { Funk and Matsuda } \\
(2002)\end{array}$ & $\begin{array}{l}\text { Macroeconomic News and Stock Returns } \\
\text { in the United States and Germany }\end{array}$ & $\begin{array}{l}\text { Typically all macroeconomic variables do } \\
\text { define stock prices. }\end{array}$ \\
\hline $\begin{array}{l}\text { Serra and Ferreira, } \\
(2020), \\
\text { Bird and Dane (2017) } \\
\end{array}$ & $\begin{array}{l}\text { ECB, BoE and Fed Monetary-Policy } \\
\text { announcements: price and volume effects } \\
\text { on European securities markets }\end{array}$ & $\begin{array}{l}\text { The overall impact of the information of } \\
\text { unconventional monetary policy measures } \\
\text { are significant for European stock markets }\end{array}$ \\
\hline $\begin{array}{l}\text { Gogstad, Kutan and } \\
\text { Muradoglu (2018), } \\
\text { Syed, Fong, Hassan, } \\
\text { and Shad (2021) }\end{array}$ & $\begin{array}{l}\text { Do international institutions affect } \\
\text { financial markets?: evidence from the } \\
\text { Greek Sovereign Debt Crisis }\end{array}$ & $\begin{array}{l}\text { The study concludes favorable effects } \\
\text { from announcements have substantial } \\
\text { impacts on returns }\end{array}$ \\
\hline $\begin{array}{l}\frac{\text { Kosmidou, }}{\text { Kousenidis, Ladas, and }} \\
\text { Negkakis (2019), } \\
\end{array}$ & $\begin{array}{l}\text { Do institutions prevent contagion in } \\
\text { financial markets? Evidence from the } \\
\text { European debt crisis. }\end{array}$ & $\begin{array}{l}\text { Whenever a county enters into external } \\
\text { debts, indigenous investors take them into } \\
\text { account seriously. }\end{array}$ \\
\hline Parab and Reddy & $\begin{array}{l}\text { The dynamics of macroeconomic } \\
\text { variables in Indian stock market: a Bai- } \\
\text { Perron approach }\end{array}$ & $\begin{array}{l}\text { Generally, major macroeconomic news } \\
\text { majorly fabricates stock prices in India }\end{array}$ \\
\hline $\begin{array}{l}\text { Hasan and Nasir } \\
(2008), \\
\text { Bird and Dane (2015) } \\
\end{array}$ & $\begin{array}{l}\text { Macroeconomic Factors and Equity } \\
\text { Prices: An Empirical Investigation by } \\
\text { Using ARDL Approach }\end{array}$ & $\begin{array}{l}\text { The reveal that significant } \\
\text { macroeconomics variables have an impact } \\
\text { on stock prices }\end{array}$ \\
\hline $\begin{array}{l}\text { Kibria, } \quad \text { Mehmood, } \\
\text { Kamran and Arshad } \\
(2014)\end{array}$ & $\begin{array}{l}\text { The Impact of Macroeconomic Variables } \\
\text { on Stock Market Returns: A Case } \\
\text { of Pakistan }\end{array}$ & $\begin{array}{l}\text { The results of Regression Analysis show } \\
\text { that the Inflation, Exchange rate, Money } \\
\text { The supply, GDP per capita, and GDP } \\
\text { savings have a positive impact on the } \\
\text { KSE } 100 \text { index. }\end{array}$ \\
\hline $\begin{array}{l}\frac{\text { Maheshwari and Rao }}{(2014), \frac{\text { Stubbs, }}{\text { Kentikelenis, and King }}} \\
\text { Kent } \\
\end{array}$ & $\begin{array}{l}\text { The long- } \\
\text { indices an }\end{array}$ & $\begin{array}{l}\text { In the long run, stock prices depend on } \\
\text { the macroeconomic movements of } \\
\text { Pakistan }\end{array}$ \\
\hline $\begin{array}{lr}\text { Ismail, } & \text { Pervaz, } \\
\text { Ahmed, and Iqbal } \\
(2016)\end{array}$ & $\begin{array}{l}\text { Macroeconomic Factors and the Pakistani } \\
\text { Equity Market: A Relationship Analysis }\end{array}$ & $\begin{array}{l}\text { Local Equity market entirely based on } \\
\text { significant economic volatility }\end{array}$ \\
\hline $\begin{array}{l}\text { Naseem, Rizwan and } \\
\text { Abbas (2017) }\end{array}$ & $\begin{array}{l}\text { Impact of Macroeconomic Variables on } \\
\text { Pakistan Stock Market }\end{array}$ & $\begin{array}{l}\text { The findings from multiple regression } \\
\text { analysis divulges a significant effect of } \\
\text { money supply and exchange rate with a } \\
\text { negative and positive sign, respectively, } \\
\text { whereas inflation and interest rates show a } \\
\text { positive, insignificant behavior toward the } \\
\text { Pakistan stock market. }\end{array}$ \\
\hline $\begin{array}{l}\text { Pervaiz, Masih, and } \\
\text { Zhou (2018) }\end{array}$ & $\begin{array}{l}\text { Impact of Macroeconomic Variables on } \\
\text { Karachi Stock Market Returns }\end{array}$ & $\begin{array}{l}\text { Macroeconomic Variables and Karachi } \\
\text { Stock Market Returns relate to each other. }\end{array}$ \\
\hline Khan (2018) & $\begin{array}{l}\text { Assessing the role of } \\
\text { Macroeconomic variables on } \\
\text { Stock price volatility: a case of } \\
\text { Pakistan stock exchange }\end{array}$ & $\begin{array}{l}\text { Macroeconomic variables including } \\
\text { interest rate, inflation rate and } \\
\text { the corporate tax rate that affect the share } \\
\text { prices of companies operating in } \\
\text { Pakistan. }\end{array}$ \\
\hline $\begin{array}{l}\text { Malik, Touqeer, and } \\
\text { Zeb (2018) }\end{array}$ & $\begin{array}{l}\text { Macroeconomic Factors and Stock } \\
\text { Returns: Evidence from the Emerging } \\
\text { Market of Asia }\end{array}$ & $\begin{array}{l}\text { The results of the study show that } \\
\text { T-bills rate has significant negative } \\
\text { impact while Exchange rate has a } \\
\text { significant positive impact on } \\
\text { the Stock Returns of the study period }\end{array}$ \\
\hline $\begin{array}{l}\text { Tahir, Gul, and Qazi } \\
\underline{\underline{(2019)}}\end{array}$ & $\begin{array}{l}\text { The causality between macroeconomic } \\
\text { factors on stock returns: a study Of } \\
\text { Pakistan equity market }\end{array}$ & $\begin{array}{l}\text { Macroeconomic factors cause market } \\
\text { returns significantly. }\end{array}$ \\
\hline
\end{tabular}

Lau and Melnish (2003) researched to check out the impact of the IMF's bailout program on the banking sector of 16 countries, including Indonesia, Thailand, and Korea, that availed the IMF bailout MVRM model, and the findings suggest that non-bailout banks have negative abnormal returns. Moreover, Hayo and Kutan (2005) investigated the stock returns and volatility of Argentinan, Brazilian, Indonesian, Pakistani, Russian, and South Korean financial markets regarding IMF events during other regional financial crises from 1997 to 1999 by employing the GARCH model. The study outcomes revealed that positive IMF news increases stock returns, but IMF news does not influence the stock 
markets' volatility. Overall the said study falls in the spectrum of how macroeconomic events fabricates stock prices in a given context. A glimpse of literature cited in Table 1 narrates that investors discount the macroeconomic events in international or national contexts while forming the par value of their security. Resultantly, the indices of given stock markets correlate with Macroeconomic news's intensity and integrity. Most countries depend on external financial assistance for corrective fiscal deficit moves. Especially, developing countries have substantial interactions with external funds providers such as IMF, ADB, World Bank, Euro-Investors groups \& so on.

The entire economic structure of fiscal deficit countries based on IMF bailouts, hence secondary market investors of said countries, heavily embarks donors' announcements towards the recipients. prices. Briefly, the countries that substantially depend on IMF trenches their stock markets actively react with each debt agreement. The economy of Pakistan majorly finances through IMF trenches since its inception. Nevertheless, most of our local scholars have established that macroeconomic variables have a significant impact on stock market performance. Meanwhile, they ignored an integral macroeconomic event: IMF announcements that strongly impact stock price each time by seeing our economy's inherited feature. Additionally, the substance is still less explored in the international arena thus far. Therefore, the said study effectively bridges this gap by exploring the probable impact of IMF announcements on Pakistan's capital market's stock retunes even though applying the most sophisticated empirical estimations, e.g., the GARCH model.

\section{METHODOLOGY}

The study intends to investigate the impact of IMF-related NEWS on stock market returns. Purposefully, revenant events have been categorized into three types maintaining consistency, namely: extended fund facility, stand-alone agreements, and comprehensive credit facility. Moreover, the detail aches in Table1. Against each understanding of landing, dummy variables are created to mark its presence or absence. However, stock return measured through KSE 100 and KSE 30 indices respectively through this equation (Bali et al., 2016):

$R_{t}=\beta 0+\varepsilon t$

$\sigma_{t}^{2}=\beta_{1}+\beta_{2} \varepsilon_{t-1}^{2}+\beta_{3} \sigma 2_{t-1}$

where $R_{t}$ shows the returns in period t. Eq.1 depicts the mean equal to the function of constant and error term. The error term, $\varepsilon_{t}$, is supposed to have variance, $\sigma_{t}^{2}$, in Eq. (2). The conditional variance of returns at time $\mathrm{t}$ is predicted based on the persistence in the last period's shocks $(\varepsilon 2 t-1)$ and the previous period's conditional variance $\sigma 2_{t-1}$. It is worth mentioning that the KSE 100 and 30 indices are valid barometers to gauge the local market performance since: they are pioneers in formation, covering a precise and relevant set of companies as nominees of respective sectors, following unbiased selection criteria, etc. Moreover, to account for auto correlations' possible issue in daily frequency observations, we use up to five self-lags to ensure that our models do not suffer from additional serial correlation across different indices. After tremendous growth in the financial sector, market capitalization rose massively from 487 to 747 entities before 2017 to close to $32.94 \%$ in 2016. Comparable, significant drawings by Pakistan through the IMF embark on the verge of probing the possible connection between market performance and external borrowing in the period above.

\section{RESULTS}

For examining the effect of lending announcements of IMF on stock market performance in Pakistan, data about dates of extended fund facility (EFF), standby arrangement (SBA), and extended credit facility (ECF) were accessed from the website of IMF. Table 2 shows date-wise announcements of IMF for extending financing facilities to Pakistan.

Table 2: Lending Announcements

\begin{tabular}{lll}
\hline Facility & Date of Arrangement & Expiration Date \\
\hline Extended Fund Facility & Sep 04, 2013 & Sep 30, 2016 \\
\hline StandbyArrangement & Nov 24, 2008 & Sep 30, 2011 \\
\hline Extended CreditFacility & Dec06, 2001 & Dec05, 2004 \\
\hline StandbyArrangement & Nov 29, 2000 & Sep 30, 2001 \\
\hline
\end{tabular}

Source: IMF Webpage Pakistan Data (History of Lending Commitments)

Table 3 shows the descriptive statistics of KSE 30 index daily observations from July 2006 to December 2017 with 2801 observations., along with three respective dummies of variant IMF lending agreements. The torpid daily average returns do second the postulation that the KSE 30 index covers blue-chip scripts' market performance only. However, Table 4 shows the results of descriptive statistics of KSE 100 index daily observations from July 1997 to Aug 2017 with 4851 obs., along with three respective dummies of variant IMF lending agreements. The tranquil daily average returns of the KSE 100 index embarks that it reflects the true projection of the economy by covering all industrial sectors' representations. 
Table 3: Descriptive Analysis KSE30

\begin{tabular}{lccccc}
\hline Variable & Obs & Mean & Std. dev & Min & Max \\
\hline Time & 2,801 & 141 & 808.7234 & 1 & 2801 \\
\hline KSE30 & 2,801 & 0.00065 & 0.024756 & -0.28875 & 1 \\
\hline SBA & 2,801 & 0.008568 & 0.092185 & 0 & 1 \\
\hline SBA & 2,801 & 0.00357 & 0.059655 & 0 & 1 \\
\hline ECF & 2,801 & 0.000714 & 0.026717 & 0 & 1 \\
\hline EFF & 2,801 & 0.004641 & 0.06798 & 0 & 1 \\
\hline Window & 2,801 & 0.516958 & 0.499802 & 0 & 1
\end{tabular}

Table 4: Descriptive table for KSE 100

\begin{tabular}{cccccc}
\hline Variable & Obs & Mean & Std. dev & Min & Max \\
\hline Time & 4,815 & 2408 & 1390.115 & 1 & 4815 \\
\hline KSE100 & 4,815 & 0.000784 & 0.01516 & -0.12378 & 0.136124 \\
\hline Standard & 4,815 & 0.006023 & 0.077381 & 0 & 1 \\
\hline SBA & 4,815 & 0.002285 & 0.047747 & 0 & 1 \\
\hline ECF & 4,815 & 0.000831 & 0.028814 & 0 & 1 \\
\hline EFF & 4,815 & 0.003115 & 0.055733 & 0 & 1 \\
\hline Window & 4,815 & 0.52378 & 0.499486 & 0 & 1 \\
\hline
\end{tabular}

To measure the time-varying volatility of return caused by lending news, we prefer using the $\operatorname{GARCH}(1,1)$ approach for all news types. Hence, the model above variance conditional on its precedent values, therefore considering the timevarying disturbance terms. Additionally, we made use of the "Heteroscedasticity-Consistent Covariance Matrix" to tackle the issue of non-normality of returns; perhaps, the results may consider more consistent as compared with OLS estimations in contras.

We estimate the following $\operatorname{GARCH}(1,1)$ process:

$$
\begin{aligned}
& R j k t=\alpha 0+\sum_{i=1}^{5} \alpha i R j k t=i+\sum_{d=1}^{D} \varphi I M F k d+\varepsilon t \\
& \mathrm{~h}_{\mathrm{t}}^{2}=\beta_{0}+\beta_{1} \mathrm{~h}_{\mathrm{t}=1}^{2}+\beta_{2} \varepsilon_{\mathrm{t}=1}^{2}
\end{aligned}
$$

$\mathrm{R}_{\mathrm{jkt}}$ represents daily index $\mathrm{i}$ on day $\mathrm{t}$, and IMF $\mathrm{kd}$ are for the $(0,1)$ dummies $(\mathrm{d}=1,2, . . \mathrm{D})$ the cover the IMF announcements effect on the respective stock indexet is Error Distribution having variance h2t and its separate mean 0 . However, it is quite probable that the error term variance may influence squared error terms of its past values, such as; $\mathrm{h} 2 \mathrm{t} \& \mathrm{~h} 2 \mathrm{t}-1$, etc. In addition to that, the general description of is also given in Eq.5 as well

$\mathrm{SMR}=\mathrm{C}+\mathrm{C}_{1}(\mathrm{SBA})+\mathrm{C}_{2}(\mathrm{ECF})+\mathrm{C}_{3}(\mathrm{EFF})+\mathrm{e} \ldots$

Table 5: Results of GARCH Model

\begin{tabular}{ccccc}
\hline Variable & Co eff & Std Error & T-Stat & Sig \\
\hline Mean & 0.003765960 & 0.000097995 & 38.43029 & 0.00000000 \\
\hline C & 0.000036514 & 0.000003094 & 11.80027 & 0.00000000 \\
\hline A & 1.073099998 & 0.039978168 & 26.84215 & 0.00000000 \\
\hline B & 0.401207553 & 0.019227918 & 20.86589 & 0.00000000 \\
\hline SBA & -0.000082597 & 0.000018592 & -4.44268 & 0.00000888 \\
\hline ECF & -0.000093237 & 0.000002455 & -37.97948 & 0.00000000 \\
\hline EFF & -0.000118064 & 0.000003301 & -35.76875 & 0.00000000 \\
\hline
\end{tabular}

The above Table 5 demonstrates the GARCH model results where the IMF lending announcement, i.e., standby agreement, extended fund facility, and the comprehensive credit facility, are dummy variables. According to the mean equation in Table 5, the $P$-value of standby agreement, extended fund facility, and the extended credit facility is 0.000 , which shows that these variables are significant and impact stock returns. The null hypothesis is that there is no relationship between lending and announcement rejected at 5\%. Turning out to the coefficients of standby agreement, extended fund facility, and the extended credit facility, we find that all the coefficients have a negative sign indicating a negative impact of IMF lending on the stock returns. The study's findings also reveal that the IMF lending announcement, i.e., standby agreement, extended fund facility, and the extended credit, negatively impact stock returns with coefficients $-0.000082,-0.000093$, and -0.00011 , respectively. Furthermore, the standby agreement variable's 
examination exhibits that IMF lending decreases the stock returns on the specific lending date. From the extended fund facility perspective, there is a -0.000093 change in stock returns on the announcement date.

\section{DISCUSSION}

The study intends to investigate the impact of IMF-related news on stock market returns. Purposefully, revenant events have been categorized into three types maintaining consistency, namely extended fund facility, stand-alone agreements, and comprehensive credit facility. Two stock indices were used in the study namely; KSE-30 index daily observations from July 2006 to December 2017 with 2801 observations.KSE-100 daily index observations from July 1997 to August 2017 with a total of 4851 observations., along with three respective dummies of variant IMF lending agreements.

The study has used the GARCH $(1,1)$ approach for all news types to measure the time-varying volatility of return caused by lending news. The said estimation technique is superior because it effectively tackles the issue of abnormality of returns; perhaps, the results may be considered more consistent than OLS estimations. GARCH model results where the IMF lending announcement, i.e., standby agreement, extended fund facility, and the extended credit facility, are dummy variables. The study's findings also reveal that the IMF lending announcement, i.e., standby agreement, comprehensive fund facility, and the vast credit, negatively impact stock returns. Furthermore, the standby agreement variable's examination exhibits that IMF lending decreases the stock returns on the specific lending date.

There are hypothetical builds that demonstrate that stock market improvement may hurt from external financial growth, for instance, Stiglitz (1993), Shleifer and Vishny (1986), Bencivenga, Smith, and Starr (1995), Bhide (1993) took note of that economic development can hinder stock exchanges. In the existing literature, most of the studies have confirmed that IMF announcements directly affect the stock market performance of the relevant country. The results of our study are found consistent with the existing literature. By further supporting the stated narrative, Pakistan's context provides a stable platform with inherited underneath features i.e. heavy dependence on IMF funding and a fast-growing stock market.

\section{CONCLUSION}

This study probed the impact of IMF-related NEWS on Pakistan's stock market since the capital market is considered the sequential barometer to learn any country's economic condition. Pakistan's economy was on the verge of default in 2013; merely a sling opinion prevailed that the country can survive a bit. With the IMF program's assistance, the government endured the jolt and achieved handsome economic growth in the coming years. However, it is the pioneer study in Pakistan, especially when the country experienced liquidity crises while the capital market demonstrated higher growth (Ahmad, Nazir \& Nafees, 2018). From the results of this study, it is established that a statistically significant relationship exists between the IMF lending news and stock market performance. Even though the IMF is the lender of last resort, it is not required because the IMF forces certain conditions on the nation that may oppose the political help needed for necessary developments. It is imagined that the IMF causes certain basic changes by imposing stringent conditions. It can cause destabilization of the confidence rather than the gain of certainty of a financial specialist.

\section{LIMITATIONS AND FUTURE DIRECTIONS}

In Pakistan, the study suggested that IMF lending can destroy investor confidence. Nevertheless, data availability limitation hinders the scope of the two leading indices. Meanwhile, the scope can further be extended by including more sectoral indices with an extended time frame and more regional markets. Future studies can be conducted by introducing political stabilization and intervention of the government policies in the research frame.

\section{ACKNOWLEDGEMENT}

We are grateful to the independent reviewers and all the members of the editorial team of HSSR for sparing their precious time and extending constructive comments that helped us a lot in improving the quality of this manuscript.

\section{AUTHORS CONTRIBUTION}

Muhammad Azeem (Principal Author) conceived the idea of this paper and worked on the introduction, methodology, and discussion section. He also developed the motivation for this study by rationalizing the research gap. Further, he also extended his guidance to coauthors in performing data analysis. He also worked to address the changes suggested by the editor and independent reviewers.

Nisar Ahmad (Corresponding Author) worked on the significance of the study, literature review, discussion, conclusion, and reference section. He also reviewed the whole paper and made significant improvements in the abstract, discussion, recommendation, and reference section. As a corresponding author, he made his best efforts in submitting a timely reply to the editor after incorporating the changes suggested by independent reviewers and the editor.

Sarfraz Hussain, Muzammil Khurshid, and Safyan Majid worked on data collection, preparation of data file, critical review of literature, analysis, and reporting of the results. They also worked on the discussion and reference section. Their efforts are commendable in the preparation of the initial draft. Thus, all authors have made a significant 
contribution to this manuscript.

\section{STATEMENT OF COMPETING INTERESTS}

This statement is to certify that the authors of this research hereby declare no competing interests regarding this article's publication.

\section{REFERENCES}

1. Ahmad, N., Nazir, M. S., \& Nafees, B. (2018). Impact of financial development and credit information sharing on the use of trade credit: Empirical evidence from Pakistan. Cogent Economics \& Finance, 6(1), 1483466. https://doi.org/10.1080/23322039.2018.1483466

2. Balima, H., \& Amadou, S. (2020). IMF-supported programs and sovereign debt crises. IMF Economic Review, 1- 39. https://doi.org/10.1057/s41308-021-00135-7

3. Ben, C., \& Robles, T.-A. (2021). The IMF, tackling inequality, and post-neoliberal 're-globalization': The paradoxes of political legitimation within economistic parameters. Globalizations, 18(1), 39-54. https://doi.org/10.1080/14747731.2020.1774325

4. Bird, G., \& Dane, G. (2015). The political economy of participation in IMF programs: A disaggregated empirical analysis. Journal of Economic Policy Reform, 18(3), 221-243. https://doi.org/10.10 $\underline{80 / 17487870.2015 .1019289}$

5. Bird, G., \& Dane, R. (2017). The effect of IMF programmes on economic growth in low income countries: An empirical analysis. The Journal of Development Studies, 53(12), 2179-2196. https://doi.org/10.10 $\underline{\text { 80/00220388.2017.1279734 }}$

6. Bencivenga, V. R., B. D. Smith and R. M. Starr (1995). Equity markets, transactions costs, and capital accumulation: An illustration. World Bank Economic Review, 10(2), 241-265. https://doi.org /10.1093/wber/10.2.241

7. Bhide, A. (1993). The hidden costs of stock market liquidity. Journal of Financial Economics,34, 31-51. https://doi.org/10.1016/0304-405X(93)90039-E

8. Bordo, M. D., \& Schwartz, A. J. (2000, December). Measuring real economic effects of bailouts: historical perspectives on how countries in financial distress have fared with and without bailouts. In Carnegie-Rochester Conference Series on Public Policy (Vol. 53, No. 1, pp. 81-167). North-Holland. https://doi.org/10.1016/S01672231(01)00028-8

9. Brealey, R. A., \& Kaplanis, E. (2004). The impact of IMF programs on asset values. Journal of International Money and Finance, 23(2), 253-270. https://doi.org/10.1016/j.jimonfin.2003.12.003

10. Couharde, C., Bennani, H., \& Wallois, Y. (2021). Do IMF Reports affect market expectations? A sentiment analysis approach(No. 2021-6). University of Paris Nanterre, EconomiX. https://ideas.repec.org /p/drm/wpaper/2021-6.html

11. Doroodian, K. (1993). Macroeconomic performance and adjustment under policies commonly supported by the International Monetary Fund. Economic Development and Cultural Change, 41(4), 849-864. https://www.journals.uchicago.edu/doi/abs/10.1086/452051? journalCode=edcc

12. Eichengreen, B., Kletzer, K., \& Mody, A. (2006). The IMF in a world of private capitalmarkets. Journal of Banking \& Finance, 30(5), 1335-1357.https://doi.org/10.1016/j.jbankfin.2005.07.002

13. Evrensel, A. Y., \& Kutan, A. M. (2007). IMF-related announcements and stock market returns: Evidence from financial and non-financial sectors in Indonesia, Korea, and Thailand. Pacific-Basin Finance Journal, 15(1), 80104. https://doi.org/10.1016/j.pacfin.2006.04.001

14. Fayad, G., Huang, C., \& Zhao, P. (2020). How do member countries receive IMF policy advice: Results from a state-of-the-art sentiment index. IMF Working Paper No. 20/7 , 1-43. https://ssrn.com/abstract=3545295

15. Fraiberger, S., Lee, D., \& Rancier, D. (2018). Media sentiment and international asset prices. NBER Working Paper 25353, Cambridge, MA: National Bureauof Economic Research, 1-38. https:// doi.10.3386/w25353

16. Funk, N., \& Matsuda, A. (2002). Macroeconmic news and stock returns: case of United Sates and Germany. International Monetery Fund , 02-339. https://ssrn.com/abstract=880947

17. Gehring, K., \& Valentin, F. (2020). Stigma or Cushion? IMF Programs and Sovereign. Journal of Development Economics ,146,102507. https://doi.org/10.1016/j.jdeveco.2020.102507

18. Georgiadis, G., \& Gräb, J. (2016). Global financial market impact of the announcement of the ECB's asset purchase program. Journal of Financial Stability, 26, 257-265. https://doi.org/10.1016/j.jfs.2016.07.009

19. Gogstad, M., Kutan, A. M., \& Muradoglu, Y. G. (2018). Do international institutions affect financial markets?: evidence from the Greek Sovereign Debt Crisis. The European Journal of Finance, 24(7-8), 584-605. https://doi.org/10.1080/1351847X.2017.1335223

20. Hasan, A., \& Nasir, Z. M. (2008). Macroeconomic factors and equity prices: An empirical investigation by using ARDL approach. The Pakistan Development Review, 501-513.https://www.jstor.org/stable/41261237

21. Hayo, B., \& Kutan, A. M. (2005). IMF-related news and emerging financial markets. Journal of International Money and Finance, 24(7), 1126-1142. https://doi.org/10.1016/j.jimonfin.2005.08.007

22. Ismail, R., Pervaz, A., Ahmed, A., \& Iqbal, R. (2016). Macroeconomic factors and the Pakistani equity market: A relationship analysis. International Journal of Innovation and Applied Studies, 15(1), 122-129. 
http://www.ijias.issr-journals.org

23. Khan, M. A. (2018). Assessing the role of macroeconomic variables on stock price volatility: A case of Pakistan Stock Exchange. Pakistan Business Review, 19(4), 928- 943. http://dx.doi.org/10.22555/pbr.v19i4.1873

24. Kibria, U., Mehmood, Y., Kamran, M., Arshad, M. U., Perveen, R., \& Sajid, M. (2014). The impact of macroeconomic variables on stock market returns: A case of Pakistan. Research Journal of Management Sciences. ISSN, 2319, 1171. http://www.isca.me/IJMS/Archive/v3/i8/1.ISCA-RJMS-2014-20.pdf

25. Kamin, S. B. (2004). Identifying the role of moral hazard in international financial markets. International Finance, 7(1), 25-59. https://doi.org/10.1111/j.1367-0271.2004.00128.x

26. Kho, B. C., \& Stulz, R. M. (2000). Banks, the IMF, and the Asian crisis. Pacific-Basin Finance Journal, 8(2), 177-216. https://doi.org/10.1016/S0927-538X(00)00007-X

27. Kentikelenis, A., Thomas, E., \& Stubbs, H. (2016). IMF conditionality and development policy space. Review of International Political Economy, 23(4), 543-582. https://doi.org/10.1080/09692290.2016.1174953

28. Kern, A., Reinsberg, B., \& Rau-Gohring, M. (2019). IMF conditionality and central bank. European Journal of Political Economy , 59, 212-229. https://doi.org/10.1016/j.ejpoleco.2019.03.002

29. Kosmidou, K. V., Kousenidis, D. V., \& Negakis, C. I. (2015). The impact of the EU/ECB/IMF bailout programs on the financial and real sectors of the ASE during the Greek sovereign crisis. Journal of Banking \& Finance, 50, 440-454. https://doi.org/10.1016/j.jbankfin.2014.03.008

30. Kosmidou, K., Kousenidis, D., Ladas, A., \& Negkakis, C. (2019). Do institutions prevent contagion in financial markets? Evidence from the European debt crisis. The European Journal of Finance, 25(7), 632-646. https://doi.org/10.1080/1351847X.2018.1552171

31. Kutan, A., \& Sudjana, B. (2003). Investor reaction to IMF actions in the Indonesian financial crisis. The Journal of Policy Reforms, 6(3), 181-190. https://doi.org/10.1080/1384128032000175780

32. Kutan, A. M., Muradoglu, G., \& Sudjana, B. G. (2012). IMF programs, financial and real sector performance, and the Asian crisis. Journal of Banking \& Finance, 36(1), 164-182. https://doi.org/10.1016 /j.jbankfin.2011.06.015

33. Lane, T., Philips, S., (2000). Does IMF financing result in moral hazard? IMF Working Paper No. 00/168, 138. https://papers.ssrn.com/sol3/papers.cfm?abstract_id=880201

34. Lau, S. T., \& McInish, T. H. (2003). IMF bailouts, contagion effects, and bank security returns. International Review of Financial Analysis, 12(1), 3-23. https://doi.org/10.1016/S1057-5219(02)00126-6

35. Maheshwari, Y., \& Rao, K. V. (2014). The long-run relationship between stock indices and macroeconomic variables. International Journal of Banking and Finance, 11, 81-96. http://www.e-journal.uum.edu.my/index.php/ijbf/article/view/8484

36. Malik, M. A. S., Touqeer, S., \& Zeb, S. (2018). Macroeconomic factors and stock returns: Evidence from the emerging market of Asia. Journal of Economic Info,5(3), 16-20. https://pdfs.semanticscholar. org/ee51/4ac3f72b78aea3052ce9883ea6aecc222732.pdf

37. Naseem, S., Rizwan, F., \& Abbas, Z. (2017). Impact of macroeconomic variables on Pakistan Stock Market. The Dialogue, 14(2) 216-222.https://ssrn.com/abstract=3492543

38. Parab, N., \& Reddy, Y. V. (2020). The dynamics of macroeconomic variables in Indian stock market: a BaiPerron approach. Macroeconomics and Finance in Emerging Market Economies, 13(1), 89-113. https://doi.org/10.1080/17520843.2019.1641533

39. Pervaiz, J., Masih, J., \& Jian-Zhou, T. (2018). Impact of macroeconomic variables on Karachi Stock Market Returns. International Journal of Economics and Finance, 10(2), 28-39.https://doi.org/10.5539/ijef.v10n2p28

40. Remi, J., \& Moradi, A. (2016). The permanent effects of transportation revolutions in poor countries. The Review of Economic and Statistics,98(2), 268-284. https://doi.org/10.1162/REST a 00540

41. Rogers, J. H., Scotti, C., \& Wright, J. H. (2014). Evaluating asset-market effects of unconventional monetary policy: a multi-country review. Economic Policy, 29(80), 749-799. https://doi.org/10.1111/1468-0327.12042

42. Sever, C., Goel, R., Drakopoulos, D., \& Papageorgiou, E. (2020). Effects of emerging market asset purchase program announcements on financial markets during the COVID-19 Pandemic. IMF Working Paper No. 2020/292, 1-22. https://ssrn.com/abstract=3772498

43. Serra, A. P., \& Ferreira, E. (2020). ECB, BoE and Fed Monetary-Policy announcements: price and volume effects on European securities markets. Banco de Portugal, Economics and Research Department Working Papers, (201914),1-40. https://efmaefm.org/0EFMAMEETINGS/EFMA\%20ANNUAL\%20MEETINGS/2019Azores/papers/EFMA2019_0377_fullpaper.pdf

44. Shleifer, A., \& Vishny, R. W. (1986). Large shareholders and corporate control. Journal of Political Economy, 94(3, Part 1), 461-488. https://www.journals.uchicago.edu/doi/pdf/10.1086/261385

45. Stiglitz, J. E. (1993). The role of the state in financial markets. The World Bank Economic Review, 7(suppl_1), 19-52.https://doi.org/10.1093/wber/7.suppl_1.19

46. Stubbs, T., Kentikelenis, A., \& King, E. (2016). Catalyzing aid? The IMF and donor behavior in aid allocation. World Development, 78, 511-528.https://doi.org/10.1016/j.worlddev.2015.10.010

47. Syed, E., Fong-, W. L., Hassan, R., \& Shad, M. K. (2021). The long-run impact of information security breach announcements on investors' confidence: The context of efficient market hypothesis. Sustainability,13(3), 1-13.

48. Tahir, M., Gul, A., \& Qazi, S. (2019). The causality between macroeconomic factors on stock returns: A study 
of Pakistan equity. International Journal of Information, Business and Management, 11(4), 212-222. http://ijibm.site666.com/IJIBM_Vol11No4_Nov2019.pdf\#page=217

49. Tillmann, P. (2001). Switching risk-perception on bond markets; Does IMF lending induce Moral Hazard?. The University of Cologne.

50. Tobias., K. (2020). Doing more with less: The catalytic function of IMF lending and the. Bundes Bank Discussion Paper, 18/2020. https://ssrn.com/abstract=3581213

51. Williams, J., \& Nguyen, N. (2005). Financial liberalization, crisis, and restructuring: A comparative study of bank performance and bank governance in South East Asia. Journal of Banking \& Finance, 29(8-9), 2119-154 https://doi.org/10.1016/j.jbankfin. 2005.03.011

52. https://www.imf.org/en/Countries/PAK\#countrydata 